\title{
Labour Market Governance and the Creation of Outsiders
}

\section{Colin Crouch}

\section{Article by an MPIfG researcher}

Colin Crouch: Labour Market Governance and the Creation of Outsiders. In: British Journal of Industrial Relations 53(1), 27-48 (2015). Wiley-Blackwell

The original publication is available at the publisher's web site: http://dx.doi.org/10.1111/bjir.12058

\begin{abstract}
Using case-study data, the article examines the contention that protective labour market policies and trade union action are responsible for growing divisions between labour market 'insiders and outsiders'. Case studies are reported on developments in collective bargaining in the hospitals and engineering sectors from seven western and central European countries. The article finds that managerial strategies, and interactions between management and unions, have to be considered to give a full account of the growth of precarious employment.
\end{abstract}

\section{Introduction}

Debates over labour market 'reform' in Europe are mainly about the role of employment protection laws in either reducing overall employment or creating divisions between protected labour market insiders and unprotected outsiders (e.g. Addison and Teixeira 2003; Avdagic 2015; Boeri 2004; Cahuc and Postel-Vinay 2002; Clark and Postel-Vinay 2009; Eichhorst 2015; European Commission 2007; Heyes 2011; Micco and Pages 2006; OECD 2004; Schmid 2015; Venn 2009). There is another debate about hypothesized distinctions between protected workers in the 'non-market' public sector and exposed workers in the private sector (Pfeifer 2011). There is then a further theme concerning collective bargaining. For orthodox economists, trade unions are labour monopolists, trying to raise artificially the price of labour, and protecting their members as privileged insiders at the expense of 'outsiders', who are either unemployed or otherwise required to bear the costs of the insiders' privileges (Lindbeck and Snower 1988; Rueda 2005, 2006; Sigeman 2009). Missing from all these formulations of the problem of outsiders is the role of employers. There is rarely any consideration that managerial strategy itself might favour the creation of grades of employee with different levels of job

Colin Crouch is at the University of Warwick. 
security, or that outsiders might be created by the interaction between employer strategy and other elements of the labour market context. The aim of the present article is to explore how these further elements might operate. It does this, first by exploring some general comparative data on European economies, and then by examining reports of case studies on developments in collective bargaining in the hospitals and engineering sectors from seven western and central European countries.

\section{Outsiders and market externalities}

The creation of labour-market outsiders can be seen as an example of the more general problem of market externalities, including the possibility that various means of tackling market failure will have characteristic failures of their own. The concept of labour market 'outsiders' implies something stronger than being at the lower end of a continuum of income or working conditions. It implies the existence of discrete cut-off points that prevent certain persons from sharing favourable conditions enjoyed by others. The simple term 'outsider' in this context covers a considerable variety of forms of exclusion, depending on what constitutes the 'inside' from which the outsiders are excluded. The unemployed are the clearest cases of outsiders, as they are excluded from active participation in the labour market. Workers in the shadow economy are excluded from the protection of the law. Workers with temporary contracts are excluded from the benefits of open-ended contracts, though the extent of their exclusion will depend on the precise terms of both forms of contract. More generally, there can be various forms of contract for workers doing similar work, the outsiders being those unable to gain access to the more privileged forms.

In theory, these issues will be played out in particular ways under different forms of labour market governance, as summarized in Table 1. Column three

TABLE 1

Characteristic Means of Dealing with Externality Problems through Definition of Labour Market Outsiders

\begin{tabular}{|c|c|c|}
\hline Forms of governance & Externality coping capacity & Definition of outsiders \\
\hline Law and government & High & $\begin{array}{l}\text { Depends on political leverage } \\
\text { of different groups }\end{array}$ \\
\hline $\begin{array}{c}\text { Associational } \\
\text { bargaining }\end{array}$ & $\begin{array}{l}\text { Depends on degree of } \\
\text { encompassingness }\end{array}$ & $\begin{array}{l}\text { Groups outside associational } \\
\text { scope }\end{array}$ \\
\hline Firm-level bargaining & $\begin{array}{l}\text { Low, unless unions can } \\
\text { introduce wider perspectives }\end{array}$ & $\begin{array}{l}\text { Groups of low importance to } \\
\text { firms, unless amended by } \\
\text { union influence }\end{array}$ \\
\hline Corporate hierarchy & $\begin{array}{l}\text { Low: limited to organizational } \\
\text { needs }\end{array}$ & $\begin{array}{l}\text { Groups of low importance to } \\
\text { firms }\end{array}$ \\
\hline Market & Low & $\begin{array}{l}\text { Groups defined by implicit and } \\
\text { incidental results of market } \\
\text { competition }\end{array}$ \\
\hline
\end{tabular}


in the table comprises hypotheses about the characteristic way that the principal forms of labour-market governance should be expected to define outsiders. However, in reality, the different forms exist alongside and in tension with each other, which means that the emergence of different groups as outsiders is a result of that interaction and not something that can be read off simply from the abstract assumptions of the table. For example, law, because of its universalist aspirations, may refuse to identify any outsider groups when allocating security rights - other than the law's implicit exclusion of persons with illegal status. But the corporate hierarchies of firms may want to free themselves of the constraints of such laws. They may do this by defining forms of contract that are not covered by the law; and certain demographic groups might be more likely to become included in these contract forms than others. In that way, an outsider category becomes defined.

This approach proposes an alternative to the normal procedure of research in this field, which makes abstract assumptions of motives. For example, in key works that established the debate over insiders and outsiders, Rueda $(2005,2006)$ drew very broad conclusions about an hypothesized tendency of social democratic parties and trade unions to favour insiders at the expense of outsiders, based on some initial assumptions about how these parties and unions derive their interests. Talani and Cerviño (2003) attempted to refute this on the basis of an analysis of unions' interests as shaped by the specific context of Spanish institutions, arguing that it was not union strategy but that of employers to make the high use of temporary workers that has become characteristic of that economy (see also Watanabe 2009).

The operation of forms of governance also depends on their detailed structure. For example, research of the kind cited above (Rueda 2005, 2006) takes for granted a US-American model of the role of unions, protecting groups of members primarily at corporation level and without a wider agenda or institutional position. In several western European countries, collective agreements have a reach extending far beyond union members, which gives unions a different set of behavioural incentives. In particular, industrial relations researchers have (following Olson 1982) concentrated on the roles of 'encompassing' bargaining, where the coverage and coordination level of bargaining are so high that it is difficult for bargainers to distinguish between the interests of their members and those of the wider workforce, or even the wider society (Traxler and Kittel 2000)

To illustrate this, Figure 1 plots union membership density against the coverage of collective agreements for a range of countries within and beyond Europe. The data are made available by the ICTWSS Database at Amsterdam (Visser 2011). Overall, there is a positive relationship between the two variables (the $r^{2}$ is 0.3714 ), but more important is the different form taken by the relationship, which becomes clear if we examine which countries make up the four quadrants formed by $>50 \%$ or $<50 \%$ on both variables. The US-based expectation of orthodox economists $(<50 \% ;<50 \%)$ certainly applies to a majority of the cases considered. The opposite quadrant $(>50 \%$; $>50 \%$ ), which we might call the case of extensive bargaining, applies, as we

(C) John Wiley \& Sons Ltd/London School of Economics 2015. 
FIGURE 1

Collective Bargaining Coverage and Union Membership Density.

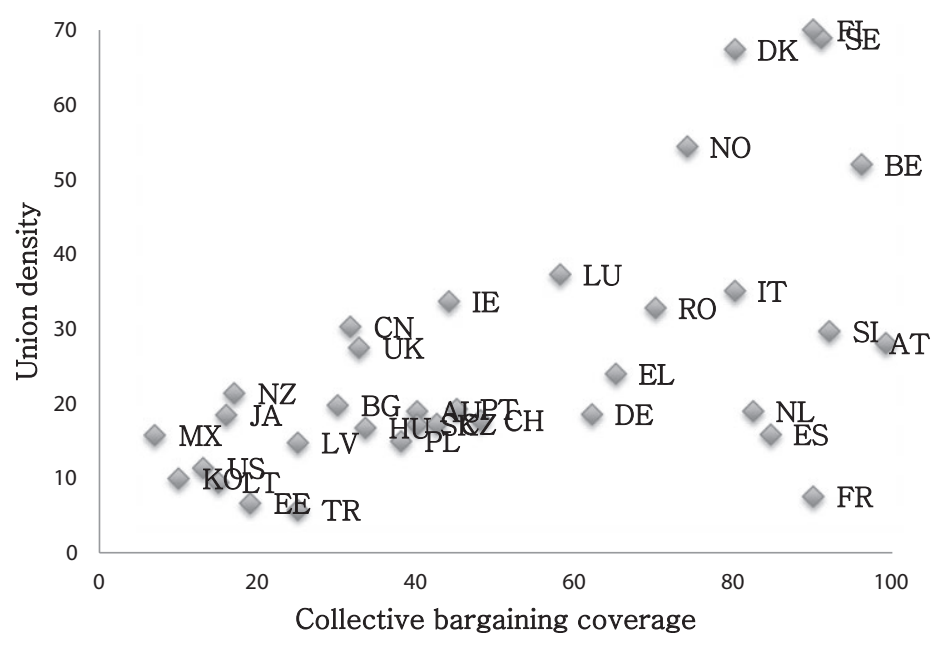

Source: Visser 2011.

might predict, to the Nordic economies, and also to Belgium. In these cases, bargaining can be 'encompassing', as discussed above. A third quadrant, where union membership would be high but coverage low $(>50 \% ;<50 \%)$ is unsurprisingly empty; but the final one, with relatively low membership but high coverage $(<50 \% ;>50 \%)$, contains a large number of western (and two central) European countries, and no country from another world region. Furthermore, only four western European cases are found in the 'orthodox' $(<50 \% ;<50 \%)$ quadrant: the two Anglophone countries (Ireland and the UK), Portugal and (just below the 50\% threshold) Switzerland. Collective bargaining in most of continental western Europe is less vulnerable to 'dog in the manger' behaviour than is assumed by economic theories rooted in experience in other parts of the world.

A more nuanced approach is needed to the study of outsiders, to consider the diversity of forms the phenomenon takes, and the way in which different forms of governance combine to produce the complex outcomes that can be observed in practice. The present article is an exploratory exercise in this process, as it pertains to insider/ outsider relations in recent crisis management. As noted earlier, it uses a number of case studies developed in research for European Union Framework Programme 7 project GUSTO (The Governance of Uncertainty and Sustainability: Tensions and Opportunities).

\section{Methods and analysis}

The general purpose of the case studies was to examine developments in collective bargaining during the recent crisis in a limited number of countries 
and sectors. The primary focus was on the role of bargaining in job protection, not wage rises. Among the issues of concern was the extent to which collective bargaining and other forms of governance reduced the insecurity of some workers by turning others into outsiders, bearing the full burden.

The case-study approach enables us to observe how different forms of governance and different economic contexts combine to produce various patterns of outsider status. However, it cannot take us further than this exploratory project. The comparisons are not systematic; the evidence was gathered in a variety of different ways. Such evidence cannot be used to test hypotheses, except for the general one that the patterns of outsider status found on the ground will be more complex than and different from those expected by the standard theories. Other methodologies would be needed to turn our tentative conclusions into hypotheses to be tested in further research.

While the detailed research methods were exploratory rather than systematic, case selection was based on criteria designed to ensure that we would capture a range of different practices within and between countries. First, we explored differences between a sector sheltered from international competition and largely in public ownership (hospitals), and one exposed to competition and in private ownership (a branch of the metal industry - cars or electronics - depending on what was important in the country concerned). Second, we considered whether the typical national level of coordination of collective bargaining made a difference to behaviour on the ground.

Combining the two variables being studied, we selected cases as follows:

- two countries with high coordination and coverage (Germany, the Netherlands);

- two that rank low on both variables (Hungary and the UK), also giving us a contrast between western and eastern European forms of this kind of ranking;

- one with high coordination but low coverage (Slovakia);

- one with low coordination but high coverage (France); and

- one with indistinct values on both variables (Italy).

In terms of the governance forms identified in Table 1, we concentrated the interactions among all except the role of law and government through employment protection laws.

National teams of researchers established what was taking place in collective bargaining. In all cases, interviews were held with managers, unions and existing researchers. In some cases, a detailed existing literature and research community could be used; in others, especially in Hungary and Slovakia, employment relations research is less developed, and more primary work had to be done by our teams. Further details of the approach taken can be found in the national reports that provided the basis for comparative analysis (Bispinck and Schulten 2010; Galetto 2011a,b; Galetto and Marginson 2011a,b; Galetto et al. 2011; Kahancová 2010a,b; Kahancová and Szabó 2011; Keune 2011; Meszman 2010; Spieser 2011; Szabó 2011; Van Klaveren 
and Tijdens 2011). Most of these articles are unpublished but can be found on the GUSTO project's website (http://www.gusto-project.eu). Because of the diversity of research methods imposed by the diversity of existing sources, it was not possible to be systematic in gathering data. As already pointed out, this limits considerably our ability to draw confident conclusions about country differences. The institutional variety in our case selection did not enable us to draw conclusions about outcomes that might be typically associated with different types, but only ensured that we could find evidence from a diversity of contexts. The analysis below draws on our case analysis to address how institutional differences did or did not appear to shape developments in, first, the hospital sector, then the metals, motors and electronics sector of the countries studied

\section{Hospital employment}

In all countries covered by our study, in both western and central Europe, we found hospital employment sharing in major general changes taking place in the special status of public employment. This takes the form of the New Public Management (NPM) approach of applying private-sector norms to public employees, either exposing them directly to market forces or using market analogues. This process predates the current crisis, but its development has become involved in crisis responses, especially in countries where NPM has been introduced only recently. NPM has been one of the main measures that governments have used to try to improve productivity in public services, confronted as they are by conflicting pressures to reduce public spending while improving public services. In our central European cases (Hungary and Slovakia), former protected civil-service status has been directly confronted; in the west it has either formally remained or never existed (UK), but where it exists, its content has been eroded.

In principle, NPM should lead to imitation of free-market private-sector practices in public employment, even if no actual privatization takes place (a process becoming known as 'corporatization' in Central and Eastern European countries (Kahancová and Szabó 2011). This should weaken co-ordinated and multi-employer collective bargaining, if not all collective bargaining. However, in only one of our countries do we find this happening in a straightforward way. The fact that governments are driving NPM and corporatization as central strategies has meant a mixed outcome of simultaneous centralization anddecentralization. Furthermore, the fact that unions almost everywhere have resisted the break-up of national, sector-level bargaining has meant a changing landscape of diverse outcomes depending on the balance of power between governments and managements on the one side and unions on the other. Even in the UK, the heartland of NPM and a country with generally weakly coordinated industrial relations, attempts by governments to dismantle the national bargaining system in favour of a single-employer model had not been successful by early 2012, though conflict 
over this continues. The exception, strangely given the country's history of highly organized industrial relations, is Germany (Bispinck and Schulten 2010). There has been not only a marked privatization of public hospitals, but there is no employers' association in the private sector, resulting in considerable disorganization of the previous industrial relations system.

Any drive to break up industrial relations institutions has also been considerably weakened by the major labour shortages that affect public health services in all our countries. Demand for health and some other public services is not a market demand that can be rationed by price, but is affected directly by strong beliefs in the public that access to the constantly increasing capacities of medical science and care practices should be widely shared. This produces pressures for increasing employment in these services, which has implications for the pay and conditions of employees. Neither consumers nor workers can be restrained by rising prices. Governments therefore have to intervene directly and prominently, trying to reconcile consumers' demands with their own desire to control public spending by suppressing health workers' pay and seeking means to improve their productivity. But these developments in turn reduce the relative attractiveness of working in the sector, exacerbating labour shortages.

As Galetto et al. (2011) point out, the introduction of NPM has had the opposite effect from that intended of producing convergence between public and private sectors, because of the political agenda that drives personnel policies in hospitals - and presumably much else in basic public services. Their conclusion is based on three countries - France, Italy and the UK but can be extended to at least the other countries in the current survey.

These overall trends are common to all our cases, with of course some differences produced by the existing institutional context. Given that NPM started in the west, particularly in the UK, it is useful to examine what has happened in central European countries. Slovakia resembles the western countries in our group (Kahancová 2010a; Kahancová and Szabó 2011). Unionization levels are relatively high and unions have been able to insist on a degree of coordination at the level of the hospital sector as a whole, while managements have sought decentralization to individual hospitals. The situation in Hungary is more complicated (Kahancová and Szabó 2011; Szabó 2011). Decentralization has taken the complex form of a devolution of administrative powers to local authorities (not individual hospitals) alongside strong fiscal centralization. Unions are also weaker than in Slovakia. However, employers and unions alike have been concerned at recruitment problems caused by depressed wages in the sector, and employers have tended to join unions in seeking to follow precedents from the pre-devolved system rather than seek a radical decentralization.

\section{NPM and 'Insider' Status}

Any discussion of whether hospital workers enjoy 'insider' status at the expense of outsiders has to be set in this paradoxical context of both moves 
to NPM and severe labour shortages. The former leads to the erosion of privileged civil service status that might be considered to constitute insider protection. New measures to improve the attractiveness of hospital employment in the context of this erosion and declining relative incomes should be seen as responses to labour shortage rather than the establishment of new privileges. Where hospital workers do enjoy privileged status, we should expect to see at least part of any expansion taking the form of the invention of new forms of labour contract, in order to produce a workforce that is less protected (i.e. creation of outsider forms of employment). Where NPM is eroding special statuses, this development is less likely.

There is evidence of this struggle in all our cases, with certain differences, but no clear distinction of the kind hypothesized can be found. A major example is the Netherlands, where there have been both major labour shortages throughout the care sector, and extensive marketization and NPM measures (Keune 2011). There has been neither an extension of general insecurity nor the creation of inferior job statuses. Instead, there have been new kinds of measure to make hospital employment attractive in the face of continuing wage restraint, such as measures to strengthen workers' rights to control their own labour time. Dutch hospitals, like much of the Dutch economy, use large amounts of part-time work, but this is not usually associated with inferior status or undertaken involuntarily.

Similarly in France, governments have started to use public sector employment as an adjustment variable, which weakens the earlier privileged status of public employees (Spieser 2011). However, since the central labour issue in hospitals has been labour shortages, this has had limited implications. Employment has remained secure, while conditions and pay have deteriorated. In compensation, hospital workers have gained some individual rights over their time management. This has been a consequence of the French 35-hour week, which has led employers in many sectors to introduce annual work-time accounts, enabling workers to budget their time across different kinds of leave (Gautié 2011). Italian health workers historically also enjoyed civil service status, but lost it in 1993 as part of a general contractualization of public employment and growth of NPM (Galetto 2011a). Developments here have been more uneven than in France or the Netherlands. In some regions in particular, it is possible to speak of privileged status and rights, with pay rises continuing to be based on general rather than productivity criteria, though in a context of budget restrictions. Within Italy, in both northern regions (that have moved furthest towards NPM and privatization) and central regions (that have maintained a model of high-quality public provision alongside NPM), collective bargaining has achieved improvements in various workers' rights alongside efficiency gains. In some other regions, primarily in the south, old models of employment survive amidst severe budget cuts, leading to deterioration in service quality.

Hospital staff in the UK have never enjoyed civil service status, so precisely the same issues have not arisen, but otherwise the situation is similar (Galetto and Marginson 2011a). British public employees usually have de facto secure 
jobs, and many of them, including hospital workers, have long benefited from the Whitley Council system of public-service employee consultation. Meanwhile, British public employees have been exposed particularly strongly to NPM reforms, which have eroded some privileged aspects of their labourmarket position. But again, major shortages of health services staff have led governments and employers to offer improvements in conditions to compensate for those being lost in NPM reforms, including deals with unions over training rights. In contrast with France and Italy, there have also been major pay rises. However, this situation may change as the UK government responds to the aftermath of the financial crisis by making reductions in National Health Service employment.

Very similar combinations of a challenge to privileged status from NPM being undermined by staff shortages have affected our two Central European cases, Hungary and Slovakia (Kahancová and Szabó 2011). In general, governments here have been more determined to press ahead with changes to employment status, to hold down pay levels, and allow shortages and consequent service deterioration to accumulate. This has occurred even though shortages are exacerbated by the emigration of trained hospital staffs to neighbouring EU countries. This pattern is seen particularly strongly in Hungary. In Slovakia, where the challenge from emigration is probably stronger, there have been improvements in working conditions to help counter the loss of staff.

Important indicators of insider/outsider differences are the use of separate categories of staff with inferior contract terms, outsourcing of services to private firms offering considerably lower security terms than enjoyed by core workers in the sector, and the growth of a shadow economy. In all countries under review, there have been significant moves by governments and managements to create dual labour markets of these kinds, with the exception of a shadow economy (illegal employment). There has, however, also been contestation from unions, and the overall outcome has been varied. In particular, it cannot be assumed that the use of temporary or agency staff necessarily means a secondary labour market not governed by bargaining institutions.

Given the above hypothesis concerning the likelihood that 'outsiders' will develop most where core staff enjoy the most privileged status, we would expect to find the UK making the least use of secondary labour markets. However, this is not the case. There has been considerable outsourcing of ancillary services such as cleaning, and also very strong reliance on agencies for providing nurses. The latter is more costly than the direct employment of nurses, which indicates that employers are prepared to pay a price to avoid having large numbers of staff on standard conditions. More recently a new grade of hospital care assistants has been introduced. These have lower qualifications than nurses, and are excluded from the sector's employment and bargaining institutions. Unions responded to this creation of an outsider labour force by insisting that government negotiate a two-tier code so that, although the labour market would remain segmented, there would at least be governance by national institutions of the new secondary sector. However, 
the change of government in 2010 led to a reversal of policy and a return to an unregulated secondary labour market.

Also in France and Italy, where there has been privileged employment status, there has been growing reliance on the employment of workers lacking public service status, with temporary contracts and on lower pay scales (Galetto 2011a; Spieser 2011). Again unions have contested these developments, sometimes successfully negotiating reductions in outsourcing or improvements in the terms of outsourced workers. Workers in private hospitals are also in principle outside the reach of the central negotiating system, and have low levels of unionization. However, at least in France, in practice, employers often find it necessary to follow public-sector agreements in order to retain staff.

There is extensive use of part-time work in the Netherlands and the UK, but part-time workers do not have inferior contract terms in those countries (Galetto and Marginson 2011a; Keune 2011). In general, it seems that across Europe, employers' determination to push ahead with NPM and unions' determination to avoid the growth of inferior forms of contract have combined to restrict the growth of insider and outsider employment statuses, apart from outsourcing some peripheral services.

In the UK, although different unions represent different categories of staff, they collaborate in the governance of the sector (Galetto and Marginson 2011a). They therefore do not behave as we hypothesized above that category unions would behave, protecting insider members at the expense of a secondary labour market. Instead, they see the growth of types of labour outside the framework of the core bargaining institutions as a threat to those institutions and therefore to their own role. It is therefore employers and (in the case of public hospitals) governments who seek to create labour market outsiders, and unions who seek inclusion. It could be argued that, were unions to be successful in their strategy of ridding hospital services of non-standard employment, or at least of submitting such employment to a form of regulation, they would only succeed in reducing overall employment in the sector. But that assumes that there is in general an oversupply of hospital staff who cannot find employment because collective bargaining is keeping labour costs too high. This is not consistent with the evidence of staff shortages and reliance on immigrant employment reported from the sector in nearly all our countries.

\section{Hospitals: A Summary of Findings}

In conclusion we return to the important fact that bargaining institutions in hospitals are caught between the two opposed forces of severe public spending constraints and labour shortages. The former leads government employers to take a firm stand in bargaining over both pay and working conditions. Models of collective bargaining usually assume private-sector employers. This is especially the case where they assume a capacity of bargainers in uncoordinated situations to externalize the costs of their activities and to create outsiders. Public-sector employers face different incentives 
(Johnston 2011). In relaxed macroeconomic situations, they may be prone to creating privileges for public employees and their services, but in times of stringency and crisis, they seem, on the basis of our case studies, to respond to macroeconomic constraints irrespective of the structure of bargaining institutions. One can still speculate whether, in the absence of the rather sector-specific bargaining structures of most hospital sectors, the public spending constraints would have exercised an even stronger pressure for changes in employee rights. Or would the need to try to attract (or not to lose) workers from these services have safeguarded employees in any case? It is notable that, among the western European countries, the two cases where bargaining is least fragmented (the Netherlands and the UK) have seen the most extensive implementation of NPM. But these countries also have among the most secure working conditions in the sector, with in particular provision for secure part-time work and, often, the inclusion of temporary workers in normal collective agreements.

The old civil-service model, coming from a period when public employees were seen as a small group of workers in a particularly strong relationship of trust with the state, is in decline. Numbers of employees seem to be too high for the guarantees of secure employment that used to be extended to the category. The old model was certainly one of privileged protection for insiders. On the other hand, the NPM model of public employment as completely assimilated to a market sector employment model is also unrealistic. First, demand for public services is not directly responsive to price, but is at least in part politically determined. This does not mean that there are no pressures restraining wages and other labour costs in public services. Public resistance to taxation and the problems caused by high levels of public debt provide powerful incentives. Where cost pressures on public employment do differ from those in the market sector is the way in which they operate. There are likely to be alternations between periods of lax pressure, when labour costs are allowed to rise, periods of exceptional restraint when fiscal concerns predominate, and episodes where labour shortages lead to large wage rises. Each of our cases exhibits something of this pattern.

\section{Metal, motors and electronics}

In contrast with hospitals, these industries all face market-derived demand. They are also manufacturing activities and are therefore liable to constant minor increments in productivity that reduce the labour requirement for a given unit of product. Also unlike hospitals, they face global competition from new low-cost producers. We therefore expect to find a very different situation from the constant labour shortages of the health sector. We should also see pressures for a decentralization of collective bargaining away from the national associational to the firm level. This is how firms should be expected to respond to global as opposed to national competitive pressures. This should be less ambiguous than the similar pressure exerted by NPM in 
hospitals, as there is no equivalent political pressure for centralization. On the other hand an overall decline in labour demand co-exists with important needs among employers to retain skills and experienced work teams during the post-2008 crisis period, because they have been assuming that this will be temporary.

\section{The Problem of Skill Retention}

We have found the issue of skill retention to be a major concern in all countries being studied. It produces a certain countervailing pressure against the overall trends in the sector. It somewhat resembles the role being played by labour shortages in hospitals, though in a different way. This is not a question of chronic labour shortage, but a fear by employers that major labour reductions in a period of crisis could damage their capacity to recover in the longer term. It has resembled the hospital situation in creating certain possibilities for constructive collective bargaining at what otherwise appears to be a period of decline for industrial relations institutions. Also as with hospitals, it sets up a certain dynamic for the position of labour-market outsiders.

Employers have wanted to retain skilled and experienced labour; unions have wanted to protect employment. That has been the basis for reaching collective agreements. Given the general weakness of post-crisis labour markets, unions have nevertheless been in a weak position in this bargaining. Their priority has been to save the jobs of existing employees, and they have been willing to trade a number of past achievements for this goal. The outcome of bargaining has also been affected by the state of play in bargaining decentralization. Where associational capacity has retained some importance, it has been possible to reach more creative solutions than where single employer bargaining predominates. As we shall see below, this also has implications for the issue of labour market outsiders.

In single-employer bargaining in the UK, unions have accepted working hours reductions, pay freezes, flexibility-enhancing arrangements and costcutting in exchange for guarantees of employment security (Galetto and Marginson 2011b). In Germany (Bispinck and Dribbusch 2011) and the Netherlands (Van Klaveren and Tijdens 2011), where more associational capacity survives, despite considerable recent erosion in the German case, it was possible for the social partners together to persuade governments to ease the path to such compromises by supporting the incomes of workers affected by these short-time deals. Similar arrangements have been made in France, where, with a low level of associational coordination, the state continues to play an important industrial relations role. These systems have been the result of remarkable tripartite consensuses. French annualized working time arrangements, briefly discussed above in connection with hospital employment, have also been used in the metals sector to bridge this gap between employers wishing to retain staff for the future but unable to provide enough work for them now (Gautié 2011). Similar strategies have also been the object 
of collective bargaining in Germany and Italy, even without the French context of an overall 35-hour week. Italian unions have also accepted hours reductions as well as derogation from statutory workers' rights (Galetto 2011b). In Slovakia, there have also been working hours reductions (Kahancová 2010b).

Only in the Netherlands does there not seem to be an employment crisis, but an overall problem of skills shortages (Van Klaveren and Tijdens 2011). However, skills shortages among key workers rest in the background of the jobs protection deals in several countries. Given that firms anticipate a recovery from recession, they know that if they will have lost key skilled work teams during the recession while competitors retained them, they will be at a disadvantage when recovery comes. Hours reduction deals and other schemes for protecting employment through the recession should not therefore be seen as compromises between employers wanting to make large numbers redundant and unions trying to avoid all redundancies. Employers have their own motives for staff retention. The tricky points in negotiations concern the precise terms of the deal.

\section{Implications for the Outsider Issue}

However, many of the arrangements that have been made have negative implications for some workers, which might be considered to become outsiders. Employers' main concern in each country has been to retain the services of experienced and skilled groups of workers, not overall employment levels. For example, German employers' strategy of maintaining core workforces led to the dismissal of large numbers of temporary workers - a return to German firms' distinction between Kernbelegschaft and Randbelegschaft (core and marginal workforces) characteristic of the years of post-war reconstruction. Following the extraordinary return to growth in the sector in 2010, employers resorted again to employing new temporary workers rather than expand their core workforce (Bispinck and Dribbusch 2011).

These changes must be seen within the context of longer-term developments in the German metal industry (Bispinck and Dribbusch 2011). Since the early 1990s, firms have been centralizing their managerial structures while decentralizing their collective bargaining and pressing down heavily on smaller supplier firms. These latter have joined with temporary workers in bearing the strain of fluctuating demand, enabling the large firms to retain their core workers. Even new recruits to the permanent workforce have often been placed on terms and conditions different from and inferior to those of existing employees. With rising productivity, there has been a gradual decline in the demand for labour. Unions have had to accept the logic of this, but have tried to ensure a socially responsible management of decline. For example, Volkswagen established its own temporary work agency that would come under some kind of negotiated governance, even if conditions were inferior to those of permanent workers. Consistently with potential 
differences in the approaches of national- and firm-level workers' representatives hypothesized above, while the union, IG Metall, has campaigned for equal treatment for agency and fixed-term employees, local works councils saw the advantages of having such a buffer protecting the core workforce.

There has been far less use of downward derogation from agreements in the Netherlands (Van Klaveren and Tijdens 2011). There are similar trends towards the use of temporary and agency workers and to increasing use of part-time workers, but this kind of employment is also subject to collective agreements. Temporary staff can be hired only from recognized agencies offering standard conditions (as in the Volkswagen case - though this is untypical in Germany), and part-time work is seen as an employee's right rather than a problem. There is, however, a similar growth in outsourcing to smaller supplier firms which might not be covered by collective agreements.

In France too there has been a large rise in temporary agency workers, right across the economy (Gautié 2011). As in the Netherlands, agency staff are in principle covered by collective agreements, though there are problems of enforcement. Employers have in recent years pursued a strategy of concentrating on core activities with their own staffs and externalizing what they regard as peripheral activities to subcontractors, who in turn achieve needed flexibility by making considerable use of temporary workers. These bore the brunt of retrenchment in 2009. As in other countries, a major consequence of this has been that young people become the main outsiders, as they have obviously had less opportunity to acquire protected and valued status by employers. French unions have tried to combat this, and there has been some success in making the rules of unemployment compensation less difficult for them, but little more. They have also campaigned on behalf of temporary workers. On the other hand, the middle-aged, middle-skilled workers in the metal industry who emerge as the protected insiders are people who would find it most difficult to find alternative jobs in other sectors.

If industrial relations in the German metal industry provide a case of managed decline, those in Hungary present one of virtually no coordination at all (Meszman 2010). Employer organizations are weak and act mainly as lobbies rather than as forms of governance; the union presence is very mixed. What bargaining takes place is only at the level of the firm. It has therefore been difficult to establish standard terms and conditions that protect an existing labour force. However, it is not the case that in this 'purer' labour market there is no recourse to divisions between insiders and outsiders. Employers, and in particular the foreign multinational corporations that dominate the sector, have sought further flexibility through the widespread employment of agency and temporary workers, and have pressed down on suppliers in a similar manner to that found in Germany. In only some cases this has involved close relations with unions, and bargaining in Hungary has shared the overall preoccupation with preserving the jobs of key workers. In the single-employer bargaining system of Hungary, unions have had to accept the dismissal of agency and temporary workers in order to protect core employment. 


\section{Metals, Motors, and Electronics: A Summary of Findings}

It is difficult to assess the overall implications of job retention deals for the insider/outsider issue. On the face of it, existing job holders are being protected at the expense of those unable to secure any work at all: a classic insider protection case. But employers can argue that, if they carried out redundancy programmes instead of such devices as working hours reduction, they would not recruit currently unemployed workers but simply increase the overall numbers of unemployed. While it might be contended that, if existing workers are made redundant, current outsiders might stand a chance of a job when the recovery starts, employers could also argue that if they lose experienced, skilled work teams, they will have no opportunity to take advantage of any recovery and will not be employing anyone at all. When the insider/ outsider distinction corresponds to differences between skilled and experienced workers and those lacking both, it cannot be interpreted simply as an issue of the protection of privileges.

Different issues affect the employment of agency and temporary workers during the crisis. These are used in several countries. As with the hospitals sector, this does not mean that unions are protecting existing members and demanding that others are placed in separate, underprivileged categories. The metal-industry unions generally oppose these categories of work, as they involve the creation of groups of worker beyond the reach of unions' negotiating achievements and undermining these. Italian unions have tried to reach bargains for restrictions in the numbers in these categories. In the UK a slightly different strategy has often been followed, with employers introducing low pay rates for new starters; unions have opposed these, usually unsuccessfully (Galetto and Marginson 2011b). In Germany, unions have also been unable to prevent employers from putting even new permanent employees on new, inferior terms and conditions (Bispinck and Dribbusch 2011).

The growth of temporary work may represent an employer strategy for coping with rigidities in the employment of core workers, in either the terms of deals negotiated with unions or in job protection laws. But employers may also have their own reasons, related to skill and experience retention, for maintaining some workers in inferior statuses in order to make credible guarantees of continuing employment to key staff and increase the chances of retaining them. The employment of agency workers is a somewhat different case. It cannot be automatically assumed that these workers are in inferior positions, though they usually are. In the UK, this varies very much from agreement to agreement (collective agreements being at firm level) (Galetto and Marginson 2011b). In the Netherlands, where national agreements govern the relationship between staff agencies and collective bargaining, collective agreements provide that temporary workers can be recruited only from agencies that offer their staff conditions similar to those of permanent staff, though this has been difficult to enforce in practice (Van Klaveren and Tijdens 2011). 
In all countries, multi-employer bargaining arrangements in the metal industry are under pressure. In some cases (e.g. Fiat in Italy and Philips in the Netherlands), the largest firms in the sector have opted out of industry-level agreements completely. There is also increasing use (especially in Germany) of derogations enabling firms to negotiate conditions inferior to those settled in a national agreement. In Hungary and the UK, single-employer bargaining is dominant. The industry thus mirrors the stereotypes of national models.

The protection of key work teams through the recession, and its associated tendency to create insider/outsider statuses, would be an employer strategy even in the absence of collective bargaining. It is possible that the presence of unions and bargaining limits the degree of relative favour shown to these key groups, given unions' tendency to want to generalize conditions across workforces if only to protect their own organizational positions.

\section{Conclusions}

The responses of employers and unions to the current crisis can be examined at two different levels: between the protected hospitals sector and the exposed metals one; and within each sector between secure job holders on the one hand and those in insecure employment or no employment at all on the other.

Any systematic insider status privileging public employees is in considerable decline following continuing pressure on public spending and the associated shift to NPM measures. In health and some other sectors, the impact of this is offset by persistent labour shortages. While these strengthen employers' interests in securing improved labour productivity, they also lead them to make employment in the sector attractive. It would be interesting to see, country by country, whether the erosion of workers' conditions has proceeded more intensely in parts of the public sector where labour shortages are not so important.

It might have been assumed that protected sectors of the economy constitute in themselves groups of insiders while exposed-sector workers are outsiders, as the former are able to restrict the impact of market forces on their employment levels and conditions. But other factors interfere with this simple logic. Protected sectors that are primarily in public employment are vulnerable to government public spending policies. Governments do not have incentives only to maintain spending levels in order to keep public employees in work and to please service consumers. They are also sensitive to tax levels and/or levels of public debt. These conflicting logics operate differently over time, with governments allowing periods where employment and pay levels are allowed to rise, followed by crises of taxation or debt, when they clamp down on pay or employment. Alternatively, periods of underfunding (to protect tax and debt levels) result in labour shortages and service deficiencies that governments seek to remedy with rapid improvements. 
Rather than systematic differences in degrees of employment security between protected and exposed sectors, there are different means of distinguishing between insiders and outsiders in the two types of sector. Public employees have historically enjoyed statuses that make it difficult to make them redundant; this dates from periods when certain grades of public employee were seen as enjoying offices of special trust under the state, which the state reciprocated by offering them security. In these cases, it is difficult for public employers to respond to funding crises with waves of redundancy of established staff. They are instead likely to favour the employment of separate categories of staff in less favourable statuses, who can more easily be made redundant: temporary, fixed-term, certain kinds of part-time contract, and agency workers. These are classic outsiders. We therefore find high levels of precarious employment, and therefore of outsiders in these sheltered sectors. This will be a generally preferred managerial strategy, unless employers can work to abolish the protected nature of core employment, in effect making all workers potential outsiders rather than having a strict division between the secure and the insecure.

The assumption that exposed industries will have few mechanisms for the protection of insiders is also seen to have many exceptions. Managers in these sectors have an interest in retaining skilled and experienced employees, which bestows on such workers a de facto security similar to that enjoyed by established public employees. Even in the absence of unions and during crises they offer guarantees to such workers. Managers calculate that, if they shed valuable employees as a response to a crisis, their firm will be poorly placed to expand again quickly when the crisis ends. In an ideal world they would discriminate among employees, dismissing those considered less capable and retaining those known to be the best. This may, however, be difficult to achieve. It may in practice not be easy to identify the best workers within teams; the atmosphere of insecurity generated by such a policy might make employment in the firm generally unpopular, as 'good' workers cannot be certain that the firm will know them to be such; and if there are collective agreements with unions, there may be rules against individual discrimination. Firms may therefore employ whole categories of temporary workers as a second-best strategy. Unions' preferred position would be to protect all employment, and certainly to oppose individual discrimination. The economic situation may make general defence impossible, in which case unions too might accept temporary employment as a second-best strategy.

The main distinction between the hospital and metals sectors in the cases considered in our study derives, not from employment status per se, but from the different organization of demand in the two sectors. The relative absence of market forces shaping demand in health, and the sector's political sensitivity, impart a different rhythm to pressures on wages, conditions and other labour costs. These do not necessarily favour health workers over their counterparts in metal, as the former can be subject to prolonged periods of wage restraint. 
Various practices can be identified as discriminating between insiders and outsiders within each sector. The evidence is seen in the role of agency workers, temporary workers and part-timers. However, as the Dutch case shows, there can be diversity in the disadvantages to which occupancy of one or other of these statuses is exposed. In some cases, they are excluded from the coverage of collective agreements; in others they are covered by agreements, but are more likely to be allocated to harsh jobs. Accounts usually given of the extent and forms of 'outsider' labour might not only err in failing to notice these differences, but they also limit attention to a few formal categories, like temporary contracts and possibly part-time working. One important form taken by outsider labour is employment in small supplier firms outside the reach of collective bargaining and sometimes even of legal regulation. We have seen these to be important in Germany as much as in CEE.

In both sectors under study, and in all countries, we have seen that employers have reasons of their own for protecting the employment of skilled and experienced workers. Collective agreements may simply articulate the terms on which this is done rather than significantly augment the numbers held in outsider status. Simplistic labour economics theories see pure markets as eroding all forms of discrimination within the labour force, leaving all workers with a roughly equal exposure to risk of employment loss. Any discrimination between insider and outsider status is seen as proceeding from employment law, the distinction between public and private sectors, and the activities of trade unions. These institutions may all contribute to some definition of outsider statuses, but the theory leaves out of consideration the role of what we called above corporate hierarchy. Employers have their own reasons for granting some individual workers or categories of workers privileged statuses, and for outsourcing some activities, particularly the least secure ones, onto supplier companies, the workers of which become de facto outsiders. While these may be different from the patterns of protection offered by employment protection law, it is very difficult to distinguish them from the interaction between managerial preferences and trade union policies that constitutes collective agreements.

It was argued above (in presenting Table 1) that there might be a trade-off between accepting externalities created by the market and accepting some labour-market outsiders. While human capital theory recognizes that employers will usually want to retain skilled and experienced work teams, and are therefore likely to treat more skilled workers differently from less skilled ones, recent macro-approaches have tended to lose sight of that motivation within a general tendency to regard workers remaining in the same employment as evidence on inefficient labour markets. It is significant that the OECD includes as one of its measures of labour market flexibility the average job tenure of employees. Countries with high levels of tenure are criticized as having rigid labour markets. This means that the most positively appraised national labour markets will be those in which employers are unable to retain or are not interested in retaining accumulations of skill and experience. 
If the importance of certain labour market externalities is recognized, the problem of outsiders becomes more complex than simply one of doing away with rigidities. Such an approach simply leaves us with the externalities, which might still have to be tackled. This is the case with middle-aged manufacturing workers who would find it hard to find any alternative employment; it is also the case with firms' desire to retain labour. The fact that recourse to temporary labour, agency staff and insecure suppliers can be found where employers seem largely in control of their labour relations demonstrates this point.

We chose our cases for analysis in this project on the basis of different overall national positions on the two important variables of bargaining coordination and coverage, in order to ensure some potential variety in the operation of bargaining. Many of the trends we have observed have been general and not limited to cases with particular positions on these variables. This is particularly true of the hospitals sector, which, as might be expected, is less characteristic of national systems than metals. In each country, managers and unions in hospitals were grappling with complex combinations of centralizing and decentralizing tendencies, overriding features of national systems. The only surprising finding was the decline in coordination affecting the German system. The metal industries, in many respects the ones that have generated what are usually taken to be the core characteristics of national systems, have not surprisingly stayed closer to national stereotypes: the state plays a large role in France because of the weakness of associations among both employers and employees; the German government was successfully lobbied jointly by employers and unions to construct some innovative jobsaving schemes; coordination also continued in the Netherlands; singleemployer bargaining dominated in Hungary and the UK. As with hospitals, there were, however, paradoxical trends in Germany, with major efforts at coordinated action taking place in a general context of a decline of associational governance.

More generally, Germany is in the midst of extensive changes, as its political and economic elites seek to weaken many of the coordinating and organizing institutions that had been characteristic of its economy (Streeck 2009). It may be significant that it is also a country where large cleavages are emerging between workers on permanent contracts and those on temporary ones. The size of this latter workforce is not as large as those in Italy or Spain, but its use by employers gives us particularly clear insights into how a contrast in the employment conditions of insiders and outsiders can serve a variety of managerial purposes.

The German case also suggests the strong possibility that, partly because of its connection to firm-level managerial preferences, decentralized bargaining is more likely than centralized bargaining to be involved in the creation of dualism, not only between sectors and firms, but also within firms. This is among the number of suggestions for more systematic research indicated by our case studies.

Final version accepted on 12 October 2013.

(C) John Wiley \& Sons Ltd/London School of Economics 2015. 


\section{Acknowledgements}

This paper draws on my work for European Union Framework Programme 7 project 'The Governance of Uncertainty and Sustainability: Tensions and Opportunities' (GUSTO) (grant no. 225301). I am particularly grateful to the colleagues within this programme who carried out the empirical work that was essential to the paper: Reinhard Bispinck, Dorothee Bohle, Heiner Dribbusch, Manuela Galetto, Marta Kahancová, Maarten Keune, Paul Marginson, Tibor Meszman, Thorsten Schulten, Catherine Spieser, Imre Szabó, Kea Tijdens and Maarten Van Klaveren.

\section{References}

Addison, J. T. and Teixeira, P. (2003). 'The economics of employment protection', Journal of Labor Market Research, XXIV (1): 85-129.

Avdagic, S. (2015). 'Does deregulation work? Reassessing the unemployment effects of employment protection', British Journal of Industrial Relations, 53 (1): 6-26.

Bispinck, R. and Dribbusch, H. (2011). 'Collective Bargaining, Decentralisation and Crisis Management in the German Metalworking Industries since 1990'. WSI Discussion paper no. 177. Dusseldorf: WSI.

— and Schulten, T. (2010). 'Metal Industry and Hospital Sector in Germany'. Unpublished GUSTO presentation.

Boeri, T. (2004). 'The effects of employment protection: learning from variable enforcement'. European Economic Review, 49 (8): 2057-77.

Cahuc, P. and Postel-Vinay, F. (2002). 'Temporary jobs, employment protection and labor market performance'. Labour Economics, 9 (1): 63-91.

Clark, A. and Postel-Vinay, F. (2009). 'Job security and job protection'. Oxford Economic Papers, 61 (2): 207-39.

Eichhorst, W. (2015). 'The unexpected appearance of a new German model', British Journal of Industrial Relations, 53 (1): 49-69.

European Commission (2007). Towards Common Principles of Flexicurity: More and better jobs through flexibility and security. Luxembourg: Office of the European Communities.

Galetto, M. (2011a). 'Collective Bargaining and the Changing Governance of Hospitals in Italy'. Unpublished GUSTO Working Paper.

- (2011b). 'Industrial Relations and Changing Governance in the Metalworking Sector in Italy in the 2000s'. Unpublished GUSTO Working Paper.

— and Marginson, P. (2011a). 'The Health Sector in Great Britain: Industrial Relations and Socio-Economic Profile'. Unpublished GUSTO Working Paper. - and - (2011b). 'The Metalworking Sector in Great Britain: Industrial Relations and Socio-Economic Profile'. Unpublished GUSTO Working Paper.

- - and Spieser, C. (2011). 'Collective Bargaining and the Changing Governance of Hospitals: A Comparison between United Kingdom, Italy and France'. Unpublished paper presented to the Industrial Relations European Conference (IREC) 2011, Barcelona, 1-2 Sept.

Gautié, J. (2011). 'France: protecting the insiders, forgetting the outsiders?'. In D. Vaughan-Whitehead (ed.), Work Inequalities in the Crisis: Evidence from Europe. Cheltenham: Edward Elgar. 
Heyes, J. (2011). 'Flexicurity, employment protection and the jobs crisis'. Work, Employment and Society, 25 (4): 642-57.

Johnston, A. (2011). European Monetary Union and Institutional Change: The Perverse Effects of Supranational Macroeconomic Regimes on Wage Inflation. Unpublished $\mathrm{PhD}$ thesis, University of London.

Kahancová, M. (2010a). 'The Healthcare Sector in Slovakia: Economic and Policy Context, IR Actors and Institutions'. Unpublished GUSTO Working Paper.

(2010b). 'The Metal Sector In Slovakia'. Unpublished GUSTO Working Paper. - and Szabó, I. G. (2011). 'Acting Private without Being Private: Hospital Corporatization and Governance of Employment Conditions in Hungary and Slovakia'. Unpublished GUSTO Working Paper.

Keune, M. (2011). 'The Hospital Sector in the Netherlands'. Unpublished GUSTO presentation.

Lindbeck, A. and Snower, D. J. (1988). The Insider-Outside Theory of Employment and Unemployment. Cambridge, MA: MIT Press.

Meszman, T. (2010). Collective Bargaining as a Mode of Governance in the Metalworking (Electronics) Sector in Hungary. Unpublished GUSTO Working Paper.

Micco, A. and Pages, C. (2006). 'The Economic Effects of Employment Protection: Evidence from International Industry-Level Data', IZA Discussion Paper no. 2433. Nuremberg: IZA.

OECD (2004). Employment Protection: The Costs and Benefits of Greater Job Security, Policy Brief. Paris: OECD.

Olson, M. (1982). The Rise and Decline of Nations. New Haven, CT: Yale University Press.

Pfeifer, C. (2011). 'Risk aversion and sorting into public sector employment'. German Economic Review, 12 (1): 85-99.

Rueda, D. (2005). 'Insider-outsider politics in industrialized democracies: the challenge to social democratic parties'. American Political Science Review, 99 (1): 61-74. (2006). 'Social democracy and active labour market policies: insiders, outsiders and the politics of employment protection'. British Journal of Political Science, 36 (3): 385-406.

Schmid, G. (2015). 'Sharing risks of labour market transitions: towards a system of employment insurance', British Journal of Industrial Relations, 53 (1): 70-93.

Sigeman, T. (2009). 'Insiders and Outsiders in the Labour Market', Papers of Stockholm Institution for Scandinavian Law: 265-78.

Spieser, C. (2011). 'The Health Sector in France: Socio-Economic Profile and Industrial Relations'. Unpublished GUSTO Working Paper.

Streeck, W. (2009). Re-Forming Capitalism: Institutional Change in the German Political Economy. Oxford: Oxford University Press.

Szabó, I. (2011). 'Collective Bargaining in the Hungarian Hospital Sector: Main actors and institutions, procedural and substantive agenda'. Unpublished GUSTO Working Paper.

Talani, L. and Cerviño, E. (2003). 'Mediterranean Labour and the Impact of Economic and Monetary Union: Mass Unemployment or Labour Market Flexibility?'. In H. Overbeek (ed.), The Political Economy of European Employment. London: Routledge.

Traxler, F. and Kittel, B. (2000). 'The bargaining system and performance: a comparison of 18 OECD countries'. Comparative Political Studies, 33 (9): 1154-90.

Van Klaveren, M. and Tijdens, K. (2011), Collective Bargaining in the Dutch Metal and Electrical Engineering Industry. Unpublished GUSTO Working Paper.

(C) John Wiley \& Sons Ltd/London School of Economics 2015. 
Venn, D. (2009). 'Legislation, Collective Bargaining and Enforcement: Updating the OECD Employment Protection Indicators', OECD Social, Employment and Migration Working Paper 89. Paris: OECD.

Visser, J. (2011). The ICTWSS Database on Institutional Characteristics of Trade Unions, Wage Setting, State Intervention and Social Pacts, 1960-2010. Amsterdam Institute for Advanced Labour Studies (AIAS), University of Amsterdam.

Watanabe, H. (2009). Politics of Labour Market Deregulation in Italy and Japan: Labour Market Flexibility and Worker Protection in an Era of Globalization. Unpublished DPhil thesis, University of Oxford. 